\title{
ISSUES OF CREATING AND TRANSLATING THE HUMAN IMAGE THROUGH ZOONYMS IN TURKISH
}

\section{Zebo Rustam Qizi Salimova}

Teacher, Department of “Turkish Philology" Tashkent State University Of Oriental Studies

\section{ABSTRACT}

This scientific article is devoted to the use of zoonyms in the expression of the human image in Turkish. The word units used to express positive and negative traits are analyzed. The breadth of language possibilities is considered in the expression of the human image through zoonyms. In Turkish, the emphasis is on the vocabulary of the language and the ways in which it is expressed in another language.

KEYWORDS: - Language, human image, character, zoonym, image, portrait, positive, negative, appearance, analogy, image, alternative, equivalent, scope of language, transfer of meaning, metaphor.

\section{INTRODUCTION}

When languages, literatures and cultures interact, they contribute to the development and enrichment of each other. Interlingual, intercultural, and literary interactions are evident in the field of translation. Today's growing globalization and integration processes pose important challenges for Uzbek translators.

Just as everything in the universe is interconnected, so humanity is closely intertwined with nature. Proof of this is the naming or simulation of human behavior, character, and appearance with the names of animals or plants. From past time to the present, it has become a tradition for bad-tempered people to be likened to wild beasts, good-natured people to domestic animals, and sensitive, mobile people to some birds.

The role of long-standing literary ties is very important in strengthening ties between the Turkish and Uzbek peoples.

It is known that the Republic of Turkey, which has a wide political, economic and cultural significance in the world, has a special place in the foreign policy of Uzbekistan. Turkey is one of the first countries to recognize the independence of Uzbekistan.

In recent years, a completely new page has been opened in the history of brotherhood, friendship and bilateral relations between our peoples, and its growth with new ideas further strengthens our relations.

The zoonyms, which are the names of the realities of the animal world, form one of the 
CURRENT RESEARCH JOURNAL OF PHILOLOGICAL SCIENCES 2(10): 108-

115, October 2021

DOI: https://doi.org/10.37547/philological-crjps-02-10-21

ISSN 2767-3758

(C)2021 Master Journals

Crossref do

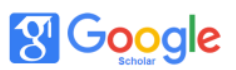

Accepted $26^{\text {th }}$ October, 2021 \& Published $31^{\text {th }}$ October, 2021

oldest semantic groups in the lexical structure of many languages. Due to the development of figurative meanings, zoolexems are actively used to describe human qualities and actions.

Belonging to a particular culture is determined by the presence of a basic stereotypical core of knowledge that is repeated in the process of socializing an individual in a particular society, so stereotypes are inappropriate names in a culture.

In our opinion, a stereotype can be expressed in different linguistic forms - lexical-semantic variants of a word, its interrelationship with other words, serving as a symbol, and so on.

The similarities and differences between the Uzbek and Turkish languages are also considered through the use of images represented by zoonyms in the annotated dictionary of both languages.

Zoonyms are a direct reflection of the ethnocultural conditions in which the lexical fund of languages is formed. A comparative analysis of the materials of lexicographic sources of Uzbek and Turkish languages allows us to talk about the existence of common and specific features in the perception of zoonymy. What they have in common is the presence of a zoonym in both language systems, including the animal's biological characteristics and zoomorphism. In both languages, zoometaphors are used to describe a person in both negative and positive ways.

From past time, mankind has been in close contact with animals and creatures. There are specific reasons for this: firstly, the animal kingdom was one of the main sources of food for humans, secondly, they served as auxiliary labor in daily life, and thirdly, they were the main means of hunting. In this regard, human tried to understand the importance obtaining the knowledge about the secrets of the animal world from past time, to keep pets close to them, to use their help effectively, or to treat wild animals with serious responsibility, and to pay special attention to them in general. Therefore, in order to further strengthen the art of folk epics, to make the plot interesting and interesting to the audience, the lion, camel, wolf, buffalo, snake, falcon, pigeon, tarlon, hawk, fox, sparrow, used the names of domestic and wild animals, such as goats, horses, crows, nightingales, hawks, beasts, various birds and animals, as a means of artistic expression. It should be noted that each of them served as a methodological tool in the text. It is well known that the emergence of the process of figurative thinking of people based on analogies and comparisons also plays an important role in the growth and consistent development of artistic thinking. The emergence of such observations has led to the desire of generations and ancestors to know the nature and the universe, to solve the mysteries that exist in it, but due to weaknesses in interpretation to evaluate them as a mysterious and divine force, as well as imaginary as a mythical image. In particular, the diversity of primitive worldviews and religious beliefs has led lions, tigers and eagles, falcons, hawks to resemble brave, courageous people; crows, ravens to stonehearted people; peacocks, nightingales to beautiful, well-behaved people; flowers, buds, and the moon, stars, and the sun to beautiful girls; the metaphor of ugly people like saxophones and saxophones is a product of the oldest notions common in oral and artistic creation ${ }^{1}$. All this is connected with the fact that humanity connects itself with the magical world

\footnotetext{
1 1. Jumanazarova G.Fozil Yo'ldosh o'glli dostonlari tilining lingvopoetikasi (leksik-semantik, lingvostilistik va lingvostatistik tahlil). - Toshkent, 2012. - B.15-16.
} 
CURRENT RESEARCH JOURNAL OF PHILOLOGICAL SCIENCES 2(10): 108-

115, October 2021

DOI: https://doi.org/10.37547/philological-crjps-02-10-21

ISSN 2767-3758

(C)2021 Master Journals

Crossref do

gil Google

Accepted $26^{\text {th }}$ October, 2021 \& Published $31^{\text {th }}$ October, 2021

of nature, or, conversely, with the behavior and inner world of human beings, that is, with comparisons, analogies, attributes, etc. they are the basis for the emergence of many means of artistic expression in our language.

The expression of the human image in the Turkish language through zoonyms is determined in accordance with the worldview and mentality of the Turkish people. In both languages there are many zoonyms that express human nature. Here are some examples.

The sample for positive stereotypes include the zoononym "kurt gibi" ("like a wulf")". This zoomorpheme, which is used to describe both a hungry person and an enterprising person, is used in the Uzbek language to describe a person who is "greedy" in a negative sense.The familiar word "kurt gibi" in the introductory sense does not express such a character in Uzbek as "kurt" or wolf. In Uzbek, the words "bo'riday" ("like a wolf") and "och bo'riday" ("like a hungry wolf") are used to describe a very hungry person. There are some differences between the two languages.

A number of Turkish zoonyms can also be seen in the expression of human portraits. For strong, young, broad-shouldered, overweight men, the term "tay gibi" ("like a horse") is used, while the term "at gibi" is used to describe stout-looking women.

A very patient, unspoken person is given "karınca sabırlı" ("ant patience") in relation to the person who performs each assigned task. In Uzbek, the same analogy is used for a hard worker. In a sense, both languages have similar meanings.

In Uzbek, the image of beautiful black eyes is used to describe "ohu" ("gazel"), "quralay" eyes, while in Turkish, the combination of "eșek gözlü" ("donkey eyes") is used to describe large and beautiful eyes.
In Uzbek, the gazelle's eye and the black eyes of a camel's child are given through the conjunctiva "quralay ko'z". The "ayl gibi" ("bear-like") compound is used for those who are sleepy and lazy, as well as those who have an awkward body structure.

There is a slight similarity between the two languages in the definition of stubbornness, which is one of the negative characteristics. In Uzbek, the word "qaysar eshshak" ("stubborn donkey") is used, while in Turkish, it is likened to a more "katir gibi" ("stubborn mule"). That is, it is represented by the compound "inatçı keçi", "eşek gibi" ("like a mule"). There are also similarities between "eșek gibi" ("stubborn donkey") and "donkey". The phrase "eşek gibi" ("like a donkey") in turn represents a rude, ignorant, foolish image. The phrase "eșekbașı" ("donkey's head") means stupid, ignorant.

According to those who do not believe in their own power and are ignored by others, the "donkey's head" ("eşekbaşı") is used.

The zoomorpheme "eșek derisi gibi" ("like the skin of a donkey") refers to a person whose skin is thick, as well as to a person who is insensitive and insensitive, and whose body structure is described as "eşek kadar" ("big as a donkey"). There are many ways in which a person's negative aspects can be expressed through a single "eshak" ("donkey") zoomorpheme.

To express negative stereotypes an ugly-looking pig ("manda") is used. The words "tonkaday", "hogkaday", "buqaday" are used in Uzbek to describe rude, very fat and lazy people, and in Turkish the word "manda gibi" is used. "Manda" means wild bull. For those who are cunning, the image of a fox is used, and the phrase "tilki gibi" ("like a fox") is used. In both languages, the same analogy is given to those who are cunning and cunning as "tulkidek ayyor" ("cunning like a fox") and "like a fox" ("tilki gibi"). 
CURRENT RESEARCH JOURNAL OF PHILOLOGICAL SCIENCES 2(10): 108-

115, October 2021

DOI: https://doi.org/10.37547/philological-crjps-02-10-21

ISSN 2767-3758

(C)2021 Master Journals

Crossref do

gil Google

Accepted26 ${ }^{\text {th }}$ October, 2021 \& Published $31^{\text {th }}$ October, 2021

A word "domuz gibi" meaning a pig-like, is used against a rude person, while traitors who take advantage of someone's work are called "çakal" ("jackals"). In Uzbek there is an animal called "sassiqkozan" which means foul odor. In the case of the animal, which is called "kokarca" in Turkish, it impersons unclean people who do not follow cleanliness and smell bad when they are not washed.

In Uzbek, a short-sighted person is likened to a "tovuq miya" ("hen brain"), while in Turkish, the phrase "tavuk gibi" ("like a hen") is used for people who fall asleep early. A phrase "horoz gibi" ("like a rooster") is used to mean a person who knows his rights and is in charge of everything. Those who get up early are compared to roosters, and those who go to bed early are compared to chickens. In Uzbek, especially in the vernacular, the term "jo'jaxo'roz" ("chicken") is used for arrogant young people who consider themselves to be in heaven, even if they can't do anything.

In the story "Horoz" ("Rooster") by the famous Turkish writer Umar Sayfiddin, we pay attention to the following passage: "Ah bu tavuklar! Dünyada bunlar kadar sevimli, bunlar kadar kendi hallerinde, bunlar kadar saf, bunlar kadar masum bir mahluk var midir. Hayatları bütün bir vezife bütün bir fedakarlık destanıdır. Bizi beslemek için muntazam yumurtlarlar. Civciv çıkarmak için haftalarca karanlıkta aç, susuz, uykusuz, güneşsiz, eğlencesiz, yumurtaların üstünde yatarlar. Kendi hararetiyle yavrularını canlandırırlar. Sonra onları büyütünceye kadar yerlerde buldukları tanelerden - obur oldukları halde- nefislerini mahrum ederler. Onları korumak için en müthiş hücumlara karşı kanat açarlar. Kendilerinin yüz misli büyük bir düşmanın üstüne atılırlar". (Ömer Seyfettin.
Horoz. S.13) ${ }^{2}$. Translation: "O poor chickens! Is there a creature in the world so beautiful, so pure, so innocent... They lay eggs every day to feed us. They lay their eggs in the dark for weeks, hungry, without water, without sleep, without light. With their heat, they keep the chickens warm. Then the chicks share what they find until they grow up.. They try to protect them from any trouble. They will fight the enemy, even if they are a thousand times stronger than they are». In this story, the protagonist represents the image of mothers through chickens. Imagine the hard work of mothers.

In another verse, "Yavaş yavaş her vakit sebepsiz bir hiddetten köpüren babamı da bu horoza benzetmeye başladım. Onun da tipinde bir horozluk vardı. Gözleri dikti, yuvarlaktı. Kalıpsız kırmızı büyük fesi tıpkı bir ibik gibi duruyordu. Öfkesiyle evi tir tir titretirdi. Annem otuz senelik karısı olduğu halde daha yanında sigara bile içemiyordu. Kardeşlerim, ağabeyim, bahçedeki yavru horozlar gibi ağız açamazlar, ona cevap veremezlerdi. Dikkat ettim, babam horoza benzediği gibi şale tarzında yapılmış evimiz de büyük bir kümese benziyordu. En iyi tünek, yani yukarıdaki balkonlu salon babamın yatak odasıydı. Biz. bütün ev halkı bir sürü tavuk... Nazarında hiç ama hiç ehemmiyetimiz yoktu. Hizmetçileri döver, uşakları kovar, mutfağa karışır, kardeşlerimi azarlar, anneme gik dedirtmez, bana göz açtırmazdı. Evde münhasıran yalnız o vardı. Kümeste horozun olması gibi..." (Ömer Seyfettin. Horoz. S.15). 3 Translation: "Gradually, I began to liken my father, who bled every hour, to this rooster. My father's character was rooster. Her eyes were burning. His crimson hat was crowned. They make the whole house tremble with rage. My

2 Ömer Seyfettin. Yüksek ökçeler.Ocak 2006.
3 Ömer Seyfettin. Yüksek ökçeler.Ocak 2006. 
CURRENT RESEARCH JOURNAL OF PHILOLOGICAL SCIENCES 2(10): 108-

115, October 2021

DOI: https://doi.org/10.37547/philological-crjps-02-10-21

ISSN 2767-3758

(C)2021 Master Journals

Crossref do

gil Google

Accepted $26^{\text {th }}$ October, 2021 \& Published $31^{\text {th }}$ October, 2021

mother can't walk freely even if their thirty years marrage life. My brothers and sisters can't open their mouths like a rooster in the yard, they don't say a word. When I look closely, our house is like a chicken farm, just like my dad is a rooster. The best room was my dad's room upstairs. Everyone in the house was like chickens on a farm, we had no place. He beat the workers, fired the servants, got involved in the kitchen, beat my brothers, didn't make fun of my mother, didn't open my eyes. He was the only one in the house. It roars alone like a rooster on a farm". In the story, proud, self-centered fathers are likened to a rooster, mothers who are patient to the teeth are like hen, and servants and children are like chickens.

The word "köpek gibi" ("dog-like") is used for a person who is lazy, arrogant, and flatters adults.

The word "akrep" means scorpion in Turkish, but the term "ciyan gibi" ("scorpion-like") is used to refer to humans, and the word "tili zahar" ("tongue of poison") is also used to describe a traitor. The metaphor of "yilan gibi" ("snakelike") can also be used to describe a poisonous person.

Another example of negative stereotypes is the combination of words "fil gibi" ("elephant-like") meaning fat. The giraffe is a herbivore that can eat the leaves at the top of a tree with its long neck. In this sense, in Uzbek, a giraffe is likened to a tall, slender man. In Turkish, a phrase "zürafa gibi" ("like a giraffe") is used to describe a man who can not not explain a single sentence. The term "devekuşu" ("ostrich") is used to describe a ma, who has no fire in his heart and who says, "if a sparrow lfy, its heart will be worried". Sleepy, sleep-loving people are compared to koalas.

The phrase "aslan gibi" ("like a lion") is widely used in art for tall, strong, healthy men. In the sense of a brave man who is not afraid of anything, the phrase "aslan yürekli" ("lionhearted") is used.

There are expressions in the Turkish language that allow you to express human characters in an artistic and effective way. For example, the phrase "mürekkep yalamış" ("ink licked") refers to people who are devoted to science and spend their lives learning, while the phrase "yüzünü köpek yalamış" ("licked the face of a dog") means a shameless, rude person.

"Tazı" is a long-legged, thin-bellied dog used for hunting rabbits. The term "tazi" is often used to describe people who are very thin and run fast.

A bear is also used to describe a fat person or a person who sleeps a lot, and is also compared to a bear in the sense of being rude and ugly. The term "ayı yürüyüşü" ("bear walk") is also used for those who walk on their hands and feet.

A phase "bog'a gibi" ("bull like") resemblance to very strong, handsome, energetic young men;

The expression "eșek gibi" ("like a donkey") in Turkish means foolish, rude, thoughtless, hardworking. For the insensitive, the phase "eșek derisi gibi" ("like donkey skin") combination is used. In Uzbek, these compounds mean a person who is not very hard-working or very stubborn. However, the term "eșek gözlü" ("donkey-eyed") is used for a person with large eyes.

In Uzbek, "burgut ko'z" ("eagle eye") and "lochin ko'z" ("falcon eye") are used to describe sharpsighted and sensitive people, while in Turkish, "şahin bakışlı" ("falcon eye") is used.

A person who finds an excuse in everything, who always withdraws, is like an "devekuşu" ("ostrich"). A word "deve" ("camels") is used to describe tall people.

The phrase "karga burun" ("crow's nose") is used to describe people with pointed noses. In fact, the crow's nose is slightly curved. People who 
CURRENT RESEARCH JOURNAL OF PHILOLOGICAL SCIENCES 2(10): 108-

115, October 2021

DOI: https://doi.org/10.37547/philological-crjps-02-10-21

ISSN 2767-3758

(C)2021 Master Journals

Crossref do

81 Google

Accepted26 ${ }^{\text {th }}$ October, 2021 \& Published $31^{\text {th }}$ October, 2021

are very thin and dark are also referred to as "karga gibi" ("crows-like").

It is also called "ceylan gibi" ("gazelle like") for women with a slender waist and slender figure. The combination of «ceylan bakışlı» ("gazelleeyed") embodies the humorous eyes that look through.

Cunning, deceitful, and mischievous people are likened to "çakal" ("jackal"). For the people who eat a lot a phase "fil gibi" ("elephant-like") is used. Slim women with a slender waist are called "butterflies" ("kelebek" in Turkish).

In both Uzbek and Turkish, a sheep and rabbit are compared to a person who obeys orders without words and does not have his own "I". The word "koyun bakisli" ("sheep-eyed") is used in the sense of wonder and astonishment. "Kedi gibi" ("like a cat") - also means submissive. Here, the phrase "Kedi gibi dört ayak üstüne düşmek" ("falling on all fours like a cat") is used to refer to a person who can easily get out of even the most difficult situations. The phrase "kedi ile harara (veya çuvala) girmek" ("to enter the harara (or sack) with a cat") applies to a person who cooperates with a helpless person, and the phrase "kedi ile köpek gibi" ("like a cat and a dog") applies to those who cannot agree with each other. The phrase "kedi cig'ere bakar gibi" ("like a cat's liver") refers to the eyes that look with lust, appetite, and desire to achieve.

The metaphor of "chumolidek mehnatkash" ("worker like an ant") is used in Turkish as well as in Uzbek, in the form of "karinca yuvasi gibi" ("like a carcass nest"), which means a congested, crowded place.

We describe those who do not lag behind as sticky mite the phraze "kanadek yopishqoq" ("like sticky mite") is used. In Turkish, the phrase "kene gibi yapışmak" («clinging like a tick») means the same thing.
People with thin and long legs are described as "leylek gibi" ("storks"). The zoononym "geyik" ("deer") is a description of a man who has been unfaithful to his wife or a relative.

The Uzbek word for snake means "sly, cunning, sometimes poisonous" for women, while the Turkish word for "traitor, cold, ugly" is "yllan gibi" ("snake-like"). At the same time, in Turkish folk literature, women are also compared in the literal sense. 'Gözlerinde ancak annemin bildiği bir yılan ışıltısıyla gülüyor'.(Y.Z.Ortaç.). Translation: She laughs with a snake glint in her eyes that only my mother knew. These two comparisons show that there are similarities in both languages.

There is a resemblance to a hard-working person who reads a lot of books, and the combination of "İnek gibi çalişkan" ("working like a cow") embodies the image of the people of the region, who endure all the injustices and work tirelessly.

Angut bird comes in the sense of stupid, rude, ugly person. "Eșek sıpası" ("a donkey's saddle") is like a naughty boy. Well-mannered, wellmannered children are likened to lambs. It also comes in the role of caressing and calling to the elder and the younger.

A word "maymun" ("monkey") is a person who behaves strangely, is partially funny, or imitates. Among the people, the zoonymy "sincap gibi" ("like a squirrel") is used to describe a person with teeth.

In determining the artistic skill of each writer, the uniqueness of creating a portrait of his hero is of particular importance. Because a portrait created by a writer is the first basis for creating an image of a literary hero. Who is involved in the events described in the play, what they look like, what they look like, and what kind of character they are, is first and foremost portrayed through their portraits. 
CURRENT RESEARCH JOURNAL OF PHILOLOGICAL SCIENCES 2(10): 108-

115, October 2021

DOI: https://doi.org/10.37547/philological-crjps-02-10-21

ISSN 2767-3758

(C2021 Master Journals

Crossref do

81 Google

Accepted $26^{\text {th }}$ October, 2021 \& Published $31^{\text {th }}$ October, 2021

The main reason why the events in the work are more impressive and attractive than in everyday life is, first of all, due to the protagonists who are at the center of the events being written.

In another example, the phrase "to'tiday" ("parrot-like") analogy is widely used in both languages to mean a person repeating and uttering a sentence Babam, ağzı alışmış, her sözün başında -Ulan, Ulan be..., -Vay anasını! diye konuşur. Yani dili biraz argoya kaçar. Fatoşda, kimden ne duyarsa papağan gibi tekrarlıyor, ne görürse öyle yapıyor, Fatoş'un babamı taklit ederek peltek peltek -Ulan be... -Vay anasını! gibisözler söylemesine bizim evde herkes bayllyorTranslation: Dad has an interesting habit - in one of the sentences "yes", "wow blue!" uses obscure words. Fatosh is the parrot who returns what he hears from anyone. He's like, "Oh, so-and-so!" The family is overjoyed (M. Hakimov's translation. G'aroyib bolalar,157) ${ }^{4}$.

In short, a comparative analysis of the materials of lexicographic sources of Uzbek and Turkish languages allows us to speak about the existence of common and specific features in the perception of zoonymy. What they have in common is the presence of a zoonym in both language systems, including the animal's biological characteristics and zoomorphism. In both languages, zoometaphors are used to describe a person in both negative and positive ways.

The analysis of the "behavior" of the zoonyms in these languages allows us to say the following:

The considered zoolexems are actively used in the texts of both languages and serve as a symbol of various human vices;

The zoonyms of both languages are used to evaluate human behavior, state, behavior, and

${ }_{4}^{4}$ M. Hakimov tarjimasi. G'aroyib bolalar, 157 attitudes both negatively and positively, which is explained by the specificity of the perception of the animal world, in which the same animal is characterized by similar traits. In both languages, similarities and differences can be seen in the characterization of human beings through zoonyms.

\section{ReFERENCES}

1. Исмоилов Ғ. Зоокомпонентли фразеологик бирликларнинг этномаданий хусусиятлари // Ўзбек тилшунослигининг долзарб масалалари. №7. -Тошкент: 2013.

2. Шабанов Ж., Хамидов Х. Уй хайвонлари номига асосланган мақол ва ибораларнинг таржимада берилиши // Таржима масалалари. № 2. -Тошкент: ТошДШИ, 2014.

3. Шомақсудов Ш., Шорахмедов Ш. Маънолар махзани. - Тошкент: Ўзбекистон миллий энциклопедияси, 2001.

4. Jumanazarova G.U. «Shirin bilan Shakar» dostonining lug'aviy va lingvopoetik xususiyatlari (Fozil Yo'ldosh o'g'li varinti asosida):Filol. fan. nomz. ...dis. avtoref. - T., 2008. -26 b.

5. Zohidov T.Z. Zoologiya ensiklopediyasi. Qushlar. - Toshkent, 1957.

6. Ibrat. «Ergash Jumanbulbul o'g'li ijodining ma'naviy qadriyatlarni yuksaltirishdagi o'rni va ahamiyati» ilmiy-amaliy anjumanining materiallari. - Samarqand: SamDU nashri, 2006. - 84 b.

7. Ishoqov F. «Zarbulmasal»dagi qush nomlariga doir // «O'zbek tili va adabiyoti» jurnali, 1973, №1. -B.46-50.

8. Ömer Seyfettin. Yüksek ökçeler.Ocak 2006. 
CURRENT RESEARCH JOURNAL OF PHILOLOGICAL SCIENCES 2(10): 108-

115, October 2021

DOI: https://doi.org/10.37547/philological-crjps-02-10-21

ISSN 2767-3758

(C)2021 Master Journals

Crossref doi) 81 Google

Accepted26 th $^{\text {October, }} 2021$ \& Published 31 ${ }^{\text {th }}$ October, 2021

9. Aziz Nesin. Şimdiki Çocuklar Harika, 74. 2005.

10. Salimova, Z. R. Q. (2021). Peculiarities of zoonyms and zoo phraseology in the expression of human image in Turkish and Uzbek languages. Asian Journal of Multidimensional Research (AJMR), 10(2), 148-158.

11. Salimova, Z. R. (2021). THE ROLE OF PHYTONIMS IN THE EMBODIMENT OF THE HUMAN IMAGE IN THE TURKISH LANGUAGE. Journal of Central Asian Social Studies, 2(03), 23-29.

12. http://www.ziyonet.com

13. http://tdk.gov.tr

14. http://kitob.uz

15. http://www.biblus.ru 